\title{
PENGEMBANGAN MEDIA PEMBELAJARAN KETERAMPILAN MENYIMAK BERBASIS ONLINE MENGGUNAKAN GOOGLE FORM DAN GOOGLE CLASSROOM
}

\author{
Wisman $^{* 1}$, Rio Kurniawan ${ }^{2}$ \\ ${ }^{1,2}$ Program Studi Pendidikan Bahasa Indonesia, Universitas Bengkulu \\ Jalan W.R. Supratman, Kota Bengkulu, Provinsi Bengkulu, 38371A, Indonesia \\ Email: wisman@unib.ac.id"1 ${ }^{* 1}$, Kurniawan22rio@yahoo.com²
}

\begin{abstract}
Abstrak
Penelitian ini bertujuan mengembangkan media pembelajaran keterampilan menyimak secara online mengunakan google form dan google classroom yang akan diujicobakan pada Mata Kuliah Keterampilan Menyimak kepada mahasiswa semester satu. Jenis penelitian yang digunakan adalah Research \& Development (R\&D). Instrumen penelitian yang digunakan yaitu tes yang dikembangkan secara online, kuesioner, dan lembar validasi ahli.. Pengembangan yang digunakan adalah model pengembangan 4D (define, design, develop, dan disseminate). Pada tahap disseminate tidak dilaksanakan secara luas karena produk hanya terbatas penggunaannya kepada mahasiswa Program Studi Pendidikan Bahasa Indonesia, FKIP Universitas Bengkulu. Hasil penelitian menunjukkan bahwa pengembangan media pembelajaran keterampilan menyimak berbasis online menggunakan google form dan google classroom layak digunakan oleh mahasiswa Program Studi Pendidikan Bahasa Indonesia, Fakultas Keguruan dan IImu Pendidikan Universitas Bengkulu. Hal ini ditunjukkan dengan penilaian berdasarkan lembar validasi ahli berada pada kualifikasi valid dengan rata-rata 4,00. Penilaian berdasarkan kuesioner respons mahasiswa berada pada kualifikasi sangat baik dengan rata-rata 3,22 . Kemudian, penilaian berdasarkan hasil tes mahasiswa berada pada kualifikasi baik dengan rata-rata 82,93.
\end{abstract}

Kata kunci: pengembangan, menyimak, google form, google classroom

\section{THE DEVELOPMENT OF LEARNING ONLINE-BASED LEARNING MEDIA IN LISTENING SKILL BY USING GOOGLE FORM AND GOOGLE CLASSROOM}

\begin{abstract}
This study aims to develop online learning media for listening skill by using google form and google classroom which is tested in the course of listening skill for the first semester students. Type of the research used is Research \& Development (R\&D). The research instruments used were online developed tests, questionnaires, and expert validation sheets. The development used was the 4D development model (define, design, develop, and disseminate). At the disseminate stage it was not widely implemented because the product was only limited to students of the Indonesian Language Education Study Program, FKIP, Bengkulu University. The results showed that the development of online-based listening skills learning media using google form and google classroom was feasible for use by students of the Indonesian Language Education Study Program, Faculty of Teacher Training and Education, University of
\end{abstract}


Bengkulu. This is indicated by the assessment based on the expert validation sheet at valid qualifications with an average of 4.00. The assessment based on the student response questionnaire is in very good qualification with an average of 3.22. Then, the assessment based on student test results is in good qualification with an average of 82.93 .

Keywords: development, listening, google form, google classroom

\section{A. Pendahuluan}

Bahasa merupakan suatu alat untuk berkomunikasi dalam kehidupan manusia karena bahasa adalah salah satu ciri khas yang dimiliki oleh manusia untuk membedakannya dengan makhluk lain (Keraf, 1997; Noermanzah, 2019). Keterampilan berbahasa terdiri dari empat aspek yakni keterampilan menyimak, berbicara, membaca, dan menulis (Tarigan, 1986). Keterampilan menyimak merupakan aspek kemampuan berbahasa yang penting dikuasai karena menyimak merupakan bagian dari keterampilan berbahasa yang paling mendominasi dipergunakan untuk berkomunikasi

Keterampilan menyimak merupakan mata kuliah wajib bagi mahasiswa di Program Studi Pendidikan Bahasa Indonesia, FKIP Universitas Bengkulu yang ditempuh pada semester satu. Mahasiswa harus dipersiapkan untuk menjadi calon guru profesional dalam bidang bahasa Indonesia. Maka dari itu, mahasiswa harus dipersiapkan agar terampil dan mampu mengajarkan kepada siswa untuk dapat menguasai keterampilan dalam kegiatan menyimak.

Tarigan (1986) menyatakan menyimak adalah suatu proses kegiatan menyimak lambang-lambang lisan dengan penuh perhatian, pemahaman, apresiasi, serta interpretasi untuk memperoleh informasi, menangkap isi atau pesan serta memahami makna komunikasi yang telah disampaikan oleh sang pembicara melalui ujaran atau bahasa lisan. Kridalaksana (1984) mengatakan menyimak adalah menyimak (listening), yaitu kemampuan menandai dan memahami wicara. Selanjutnya dari segi leksis, menurut Wiranty (2019) menyimak berarti memperhatikan baik-baik apa yang diucapkan atau dibaca orang lain sehingga memahami makna pesan yang disampaikan.

Achsin (1981), menjelaskan menyimak sebagai suatu rangkaian proses kognitif mulai dari proses mengidentifikasikan pada tingkat fonologi, morfologi, 
sintaksis, dan semantik, sampai dengan keterlibatan aktif panca indera, khususnya alat-alat pendengaran. Kemudian, Achsin juga menambahkan (dalam Nursaid, 2001) menyimak merupakan aktivitas mental yang melibatkan serangkaian proses. Proses tersebut adalah. Pertama, mengidentifikasikan bunyibunyi atau sound identification. Kedua, menyusun pemahaman dan penafsiran atau contructing process. Ketiga, proses penggunaan hasil pemahaman dan penafsiran atau utilization process. Keempat, proses penyimpanan atau storage.

Pembelajaran berbasis online merupakan suatu kegiatan pembelajaran dengan mengunakan internet sebagai sarana utama untuk menyelesaikan pekerjaan (Irawan, 2011:30). Belajar online dikenal juga dengan istilah pembelajaran elektronik, e-learning, online learning, internet-enabled learning, virtual learning, atau web-based learning (Maulidi, 2015). Menurut Hartley (2001), e-learning merupakan suatu jenis belajar mengajar yang memungkinkan tersampaikannya bahan ajar ke siswa dengan menggunakan media internet, intranet atau media jaringan komputer lain.

Pembelajaran online yang digunakan adalah google form dan google classroom. Penggunaan google form dan google classroom pada Mata Kuliah Keterampilan Menyimak ini juga didukung oleh kondisi sebagian besar mahasiswa saat ini. Sebagian besar mahasiswa sudah menggunakan gawai yang mendukung penggunaan aplikasi google form dan google classroom, sehingga tidak ada hambatan berarti bagi mereka untuk mengakses aplikasi tersebut. Penelitian ini juga sejalan dengan Keputusan Bersama 4 Menteri Nomor 01/KB/2020 tanggal 15 Juni 2020 tentang Panduan Penyelenggaraan Pembelajaran pada Tahun Ajaran 2020/2021 dan Tahun Akademik 2020/2021 di Masa Pandemi Corona Virus Disease (Covid-19).

Google form sangat cocok untuk berbagai kalangan, seperti guru, dosen, mahasiswa, dan profesi lainnya yang senang membuat kuis dan survei online (Mansor, 2012). Selanjutnya menurut Hamdani dkk. (2017), google form merupakan salah satu layanan yang diberikan google untuk kelola pendaftaran acara, jejak pendapat, membuat kuis, dan melakukan kuis secara online. Menurut Jahroh (2018:26), beberapa fungsi google form untuk dunia pendidikan adalah 
sebagai berikut: (1) memberikan tugas latihan/ulangan online melalui website; (2) mengumpulkan pendapat orang lain melalui laman website; (3) mengumpulkan beberapa data siswa/guru melalui laman website; (4) membuat formulir pendaftaran online untuk sekolah; dan (5) membagikan kuesioner kepada orangorang secara online.

Menurut Afrianti (2018:11) google classroom didesain untuk empat pengguna yaitu pengajar, siswa, wali, dan administrator. Bagi pengajar dapat digunakan untuk membuat dan mengelola kelas, tugas, nilai serta memberikan masukan secara langsung (realtime). Untuk siswa dapat memantau materi dan tugas kelas, berbagi materi dan berinteraksi dalam aliran kelas atau melalui email, mengirim tugas dan mendapat masukan dan nilai secara langsung. Untuk wali dapat dugunakan untuk mendapat ringkasan email terkait tugas siswa. Menurut Savitri, (2019:22) pembelajaran mengggunakan alat komunikasi google classroom dapat membantu pendidik dan peserta didik melalui sebuah PC yang membutuhkan jaringan internet, namun dapat diakses dalam kelompok dalam waktu bersamaan di tempat yang berbeda-beda.

Berdasarkan studi kepustakaan dan pelacakan hasil-hasil penelitian yang relevan dengan penelitian ini, ditemukan dua hasil penelitian. Penelitian pertama Asi (2017) melakukan penelitian dengan judul "Pengembangan Bahan Ajar Kimia Bahan Makanan Berbasis Web." Berdasarkan hasil penelitiannya, bahan ajar kimia bahan makanan berbasis web layak digunakan sebagai media bahan ajar di Program Studi Pendidikan Kimia, FKIP Universitas Palangka Raya. Selanjutnya Rachmawati \& Kurniawati (2020) melakukan penelitian dengan judul "Pengembangan Instrumen Penilaian Tes Berbasis Mobile Online pada Prodi Pendidikan Matematika." Berdasarkan hasil penelitiannya, instrumen penilaian tes mobile online berbantuan google form yang dikembangkan layak digunakan untuk evaluasi pembelajaran. Penelitian ini berbeda dari penelitian sebelumnya. Perbedaannya adalah objek penelitian dan fokus penelitian. Objek yang diteliti adalah mahasiswa Program Studi Pendidikan Bahasa Indonesia, FKIP Universitas Bengkulu dan fokus penelitian mengenai pengembangan media pembelajaran 
keterampilan menyimak berbasis online mengunakan google form dan google classroom.

Demi mengatasi berbagai kendala tersebut salah satu cara yang dapat dilakukan adalah memaksimalkan penggunaan teknologi digital yang telah tersedia saat ini. Teknologi yang dapat dilakukan diantaranya dengan memanfaatkan fasilitas google form dan google classroom yang tersedia pada menu google saat ini. Bertitik tolak dari penjelasan tersebut maka penelitian ini penting untuk dilakukan penelitian tentang pengembangan media pembelajaran keterampilan menyimak berbasis online mengunakan google form dan google classroom mahasiswa Program Studi Pendidikan Bahasa Indonesia, FKIP Universitas Bengkulu.

\section{B. Metode Penelitian}

Penelitian ini menggunakan metode penelitian dan pengembangan, terutama dalam mengembangkan media pembelajaran, yakni pengembangan media pembelajaran keterampilan menyimak secara online mengunakan google form dan google classroom yang akan diujicobakan pada Mata Kuliah Keterampilan Menyimak mahasiswa semester satu, Program Studi Pendidikan Bahasa Indonesia, FKIP Universitas Bengkulu. Teknik pengumpulan data dengan cara mengumpulkan berbagai informasi yang diperlukan, mendesain media pembelajaran, mengembangkan produk awal menjadi produk akhir, dan mengembangkan media pembelajaran. Instrumen penelitian ini adalah lembar validasi ahli, kuesioner respon mahasiswa, dan soal tes.

Hasil penelitian dan pengembangan ini adalah produk media pembelajaran. Menurut Sugiyono (2012), pengembangan berarti memperdalam dan memperluas pengetahuan, tindakan, dan produk yang telah ada. Pengembangan ini menggunakan metode penelitian dan pengembangan model pengembangan 4D. Langkah-langkah model pengembangan 4D terdiri dari tahap define, design, develop, dan disseminate (Thiagarajan dkk., 1974). 
Langkah-langkah penelitian melalui tahapan sebagai berikut.

1. Tahap Define (Pendefinisian)

Tahap define adalah kegiatan mengumpulkan berbagai informasi yang diperlukan (Asi, 2017). Tujuannya adalah untuk menetapkan dan menentukan kebutuhan instruksional. Selama analisis, ditentukan tujuan untuk bahan instruksional. Ada lima langkah yang harus ditempuh pada tahap define yaitu analisis awal-akhir, analisis evaluasi peserta didik, analisis tugas, dan analisis konsep (Rachmawati \& Kurniawati, 2020).

2. Tahap Design (Perancangan)

Tahap design adalah kegiatan mendesain media pembelajaran keterampilan menyimak secara online mengunakan google form dan google classroom. Langkah ini dapat ditempuh setelah penentuan tujuan atau sasaran instrumen. Pemilihan media dan format untuk bahan dan produksi sebuah versi awal media pembelajaran merupakan aspek utama dari tahap desain (Thiagarajan dkk., 1974).

3. Tahap Develop (Pengembangan)

Tahap develop adalah kegiatan mengembangkan produk awal menjadi produk akhir (Asi, 2017). Pengembangan pada penelitian ini adalah pengembangan media pembelajaran keterampilan menyimak secara online mengunakan google form dan google classroom.

4. Disseminate (Penyebarluasan)

Tahap disseminate adalah kegiatan penyebarluasan media pembelajaran keterampilan menyimak secara online mengunakan google form dan google classroom. Pada tahap ini penyebarluasan penelitian hanya terbatas penggunaanya pada Program Studi Pendidikan Bahasa Indonesia, FKIP Universitas Bengkulu. Penyebarluasan media pembelajaran dibagikan melalui grup WhatsApp dan google classroom. Untuk lebih jelaskan langkah-langkah pengembangan media pembelajaran keterampilan menyimak berbasis online menggunakan google form dan google classroom, dapat dilihat pada gambar berikut. 


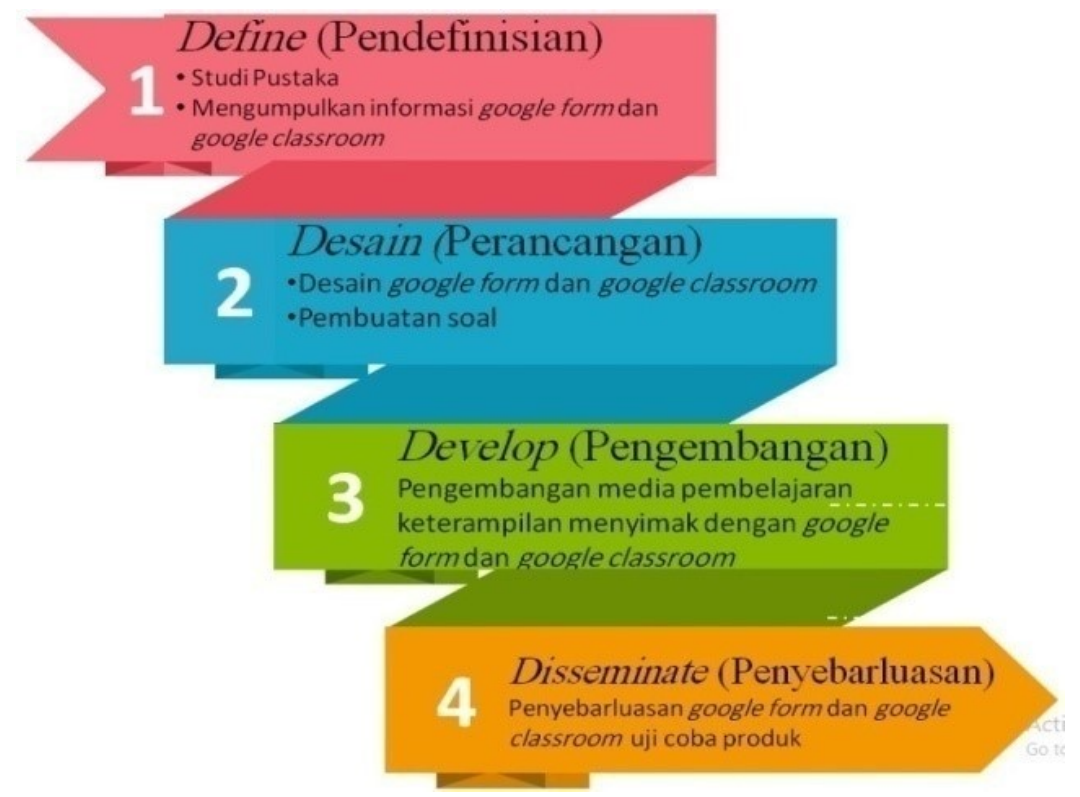

Gambar 1. Langkah-Langkah Pengembangan Media Pembelajaran Keterampilan Menyimak Mengunakan Google Form dan Google Classroom

\section{Hasil Penelitian dan Pembahasan}

\section{Hasil Penelitian}

a. Tahap Define (Pendefinisian)

Tahap define merupakan tahap awal dalam pengembangan Mata Kuliah Keterampilan Menyimak. Tahap ini mengumpulkan berbagai materi ajar, soal pendalaman materi, dan teknis pelaksanaan google form dan google classroom. Materi ajar dan soal pendalaman materi Mata Kuliah Keterampilan Menyimak dikembangkan dari berbagai referensi.

Penggunaan google form dan google classroom pada Mata Kuliah Keterampilan Menyimak ini juga didukung oleh kondisi Covid-19 dan semua mahasiswa saat ini menggunakan telepon seluler. Semua mahasiswa sudah memiliki telepon seluler yang mendukung penggunaan aplikasi google form dan google classroom sehingga tidak ada hambatan berarti bagi mereka untuk mengakses aplikasi tersebut. Apalagi google form dan google classroom bukanlah sebuah aplikasi khusus yang harus diunduh dengan kebutuhan memori tertentu. Mahasiswa cukup klik tautan untuk terhubung dengan aplikasi tersebut. 
Google form dan google classroom untuk media pembelajaran keterampilan menyimak dianggap penting untuk diketahui dan digunakan karena penggunaannya tidak berbasis instalasi listrik ataupun kabel, sehingga memudahkan pelaksanaan latihan, UTS, UAS, dan tes lainnya. Kemudahan lainnya yang dirasakan adalah cepatnya proses pembuatan dan pelaksanaan tes serta tidak menggunakan hosting pribadi melalui komputer sebagai hard drive utama, dan menyalurkan menggunakan kabel LAN atau wajib menggunakan jaringan yang sama, sedangkan google form dan google classroom menggunakan hosting cloud secara gratis dan mudah penggunaannya.

b. Tahap Design (Perancangan)

Tahap design merupakan perancangan instrumen Mata Kuliah Keterampilan Menyimak menggunakan google form dan google classroom. Tahap ini menyusun soal dan kunci jawaban tes, menyusun materi perkuliahan, dan membuat email google untuk mengakses layanan google, memilih desain template yang sesuai, membuat instrumen evaluasi online dengan google form, membuat instrumen dengan google classroom, mengecek pratinjau, memberikan pengaya, dan memperpendek tautan dengan bantuan $\underline{\text { http://gq.gq/. }}$.

Peneliti memilih 25 butir soal yang akan diujikan pada latihan keterampilan menyimak menggunakan google form dan mengelola soal tersebut agar dapat didistribusikan kepada mahasiswa agar dapat diakses secara online. Persiapan selanjutnya yang harus dilakukan yaitu menyiapkan email google untuk mengakses layanan google.

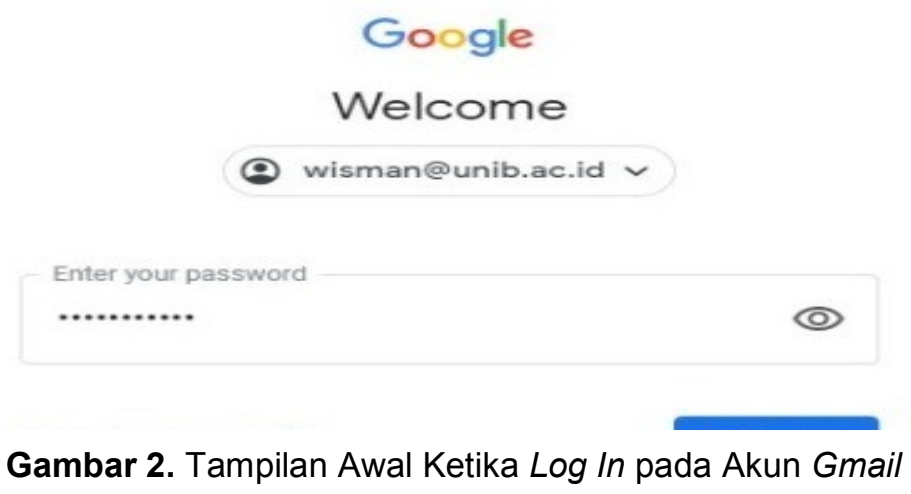

Silampari Bisa: Jurnal Penelitian Pendidikan Bahasa Indonesia, Daerah, dan Asing Vol. 3, No. 2, 2020 


\section{1) Google Form}

Google form merupakan layanan online dari google untuk membuat kuis online, survei tentang efektivitas pengajaran, mengumpulkan jawaban pertanyaan terbuka, mengumpulkan data, komentar, dan lainnya. Google form sangat cocok untuk berbagai kalangan, seperti guru, dosen, mahasiswa, dan profesi lainnya yang senang membuat kuis dan survei online (Mansor, 2012). Selanjutnya menurut Hamdani dkk. (2017), google form merupakan salah satu layanan yang diberikan google untuk kelola pendaftaran acara, jejak pendapat, membuat kuis, dan melakukan kuis secara online. Pada google form terdapat tanggapan survei yang diolah menjadi sebuah grafik lingkaran.

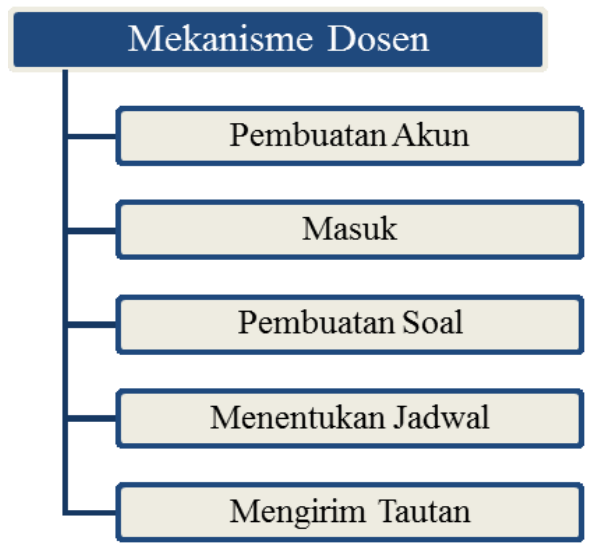

\section{Mekanisme Mahasiswa}

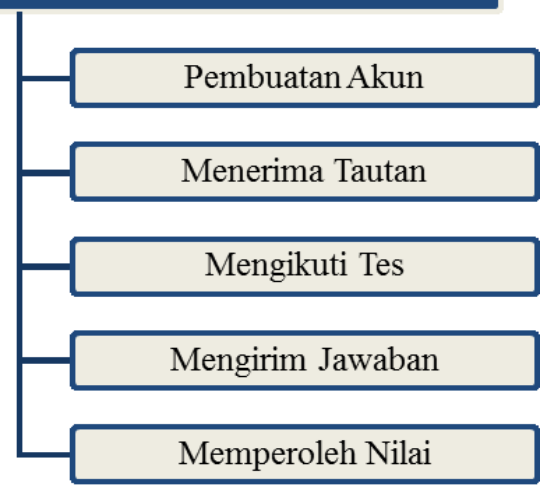

Gambar 3. Mekanisme Dosen dan Mahasiswa dalam Google

Fungsi google form pada tahap design adalah untuk pembuatan butir-butir soal yang diujikan pada Mata Kuliah Keterampilan Menyimak. Peneliti memilih 25 butir soal yang akan diaplikasikan pada latihan keterampilan menyimak menggunakan google form. Masing-masing soal memiliki bobot penilaian 4 poin, sehingga apabila mahasiswa mampu menjawab seluruh soal latihan, maka mereka akan memperoleh skor maksimal yakni 100 poin. Pada kegiatan ini peneliti merancang soal yang jawabannya berupa pilihan ganda, jenis soal yaitu empat soal dialog dan empat soal monolog, batasan waktu yang diberikan 40 menit.

Rancangan instrumen pengembangan Mata Kuliah Keterampilan Menyimak menggunakan google form terdiri dari 9 bagian. Bagian pertama meminta 
mahasiswa mengisi data diri. Data diri terdiri dari NPM, Nama Lengkap, dan Kelas. Mengisi data diri wajib diisi, jika tidak diisi maka mahasiswa tidak dapat melanjutkan pada bagian berikutnya. Data diri bertujuan untuk memberikan identitas mahasiswa.

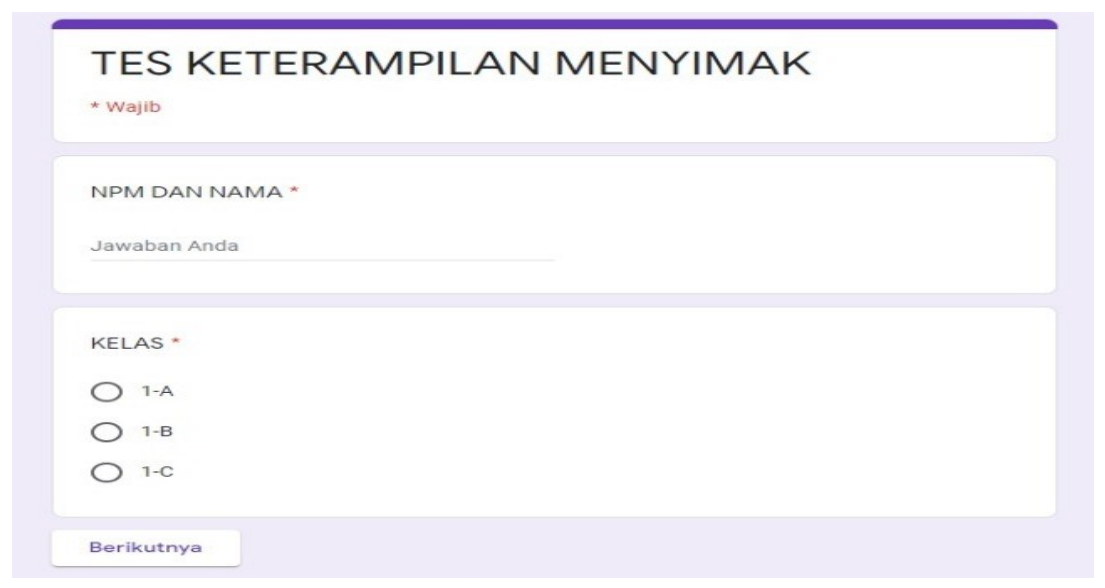

\section{Gambar 4. Tampilan Mengisi Data}

Bagian kedua sampai bagian kelima materi dialog, materi ini sebanyak 4 dialog. Menurut Solihah (2015), tujuan materi dialog adalah untuk mengukur keterampilan aktif reseptif dalam keterampilan menyimak. Setiap soal dijawab dengan memilih satu dari empat alternatif jawaban, yaitu (a), (b), (c), atau (d).
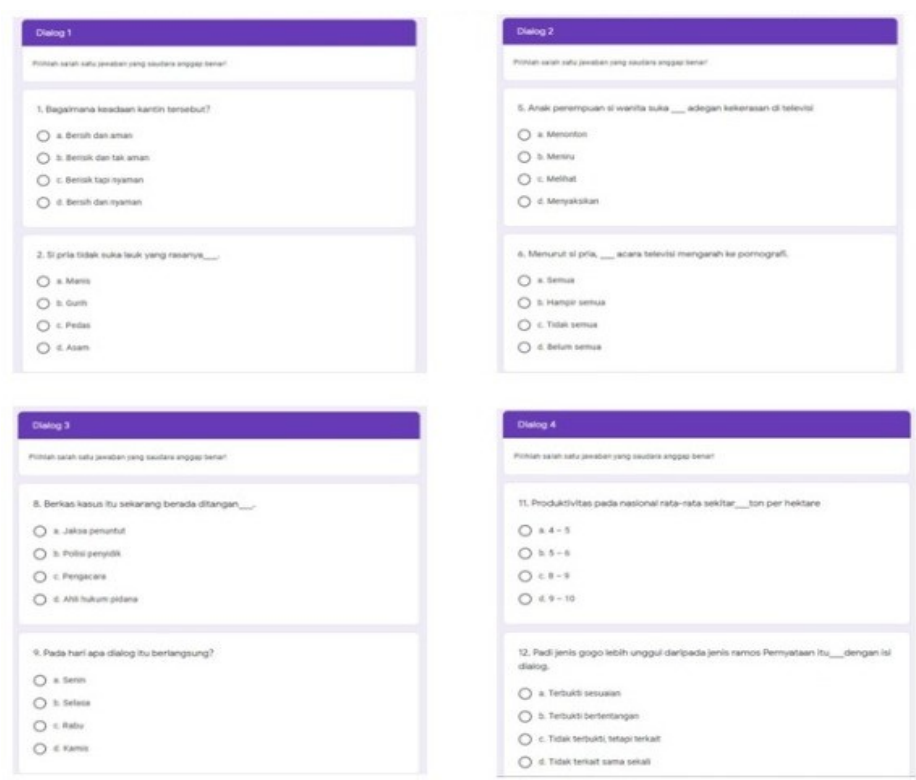

Gambar 5. Tampilan Soal Dialog

Silampari Bisa: Jurnal Penelitian Pendidikan Bahasa Indonesia, Daerah, dan Asing Vol. 3, No. 2, 2020 
Bagian keenam sampai bagian kesembilan materi monolog, materi ini sebanyak 4 monolog. Menurut Solihah (2015), tujuan materi monolog adalah untuk mengukur keterampilan aktif reseptif dalam keterampilan menyimak. Setiap soal dijawab dengan memilih satu dari empat alternatif jawaban, yaitu (a), (b), (c), atau (d).
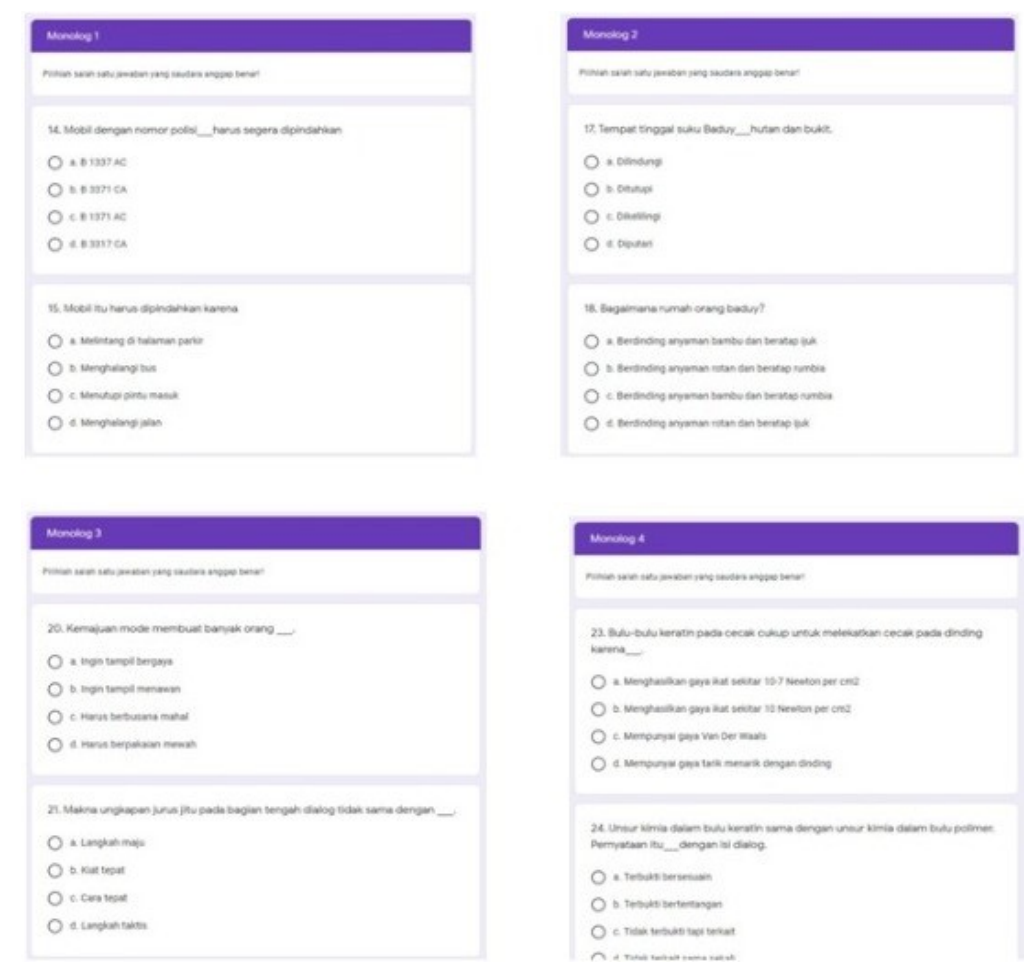

Gambar 6. Tampilan Soal Monolog

Pada google form dosen tidak perlu repot untuk mengoreksi hasil pekerjaan mahasiswa karena google form telah menyediakan fasilitas koreksi secara otomatis. Hasil jawaban masing-masing peserta latihan dan kesimpulan hasil pembelajaran juga dapat dilihat dengan sangat rinci. Berikut hasil latihan keterampilan menyimak yang diperoleh, hasil ini langsung tersedia setelah pelaksanaan proses latihan selesai dikerjakan oleh mahasiswa. 


\section{Wawasan}

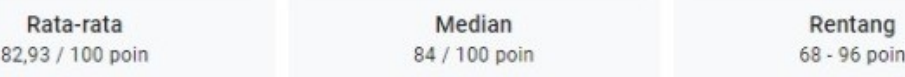

Distribusi poin total

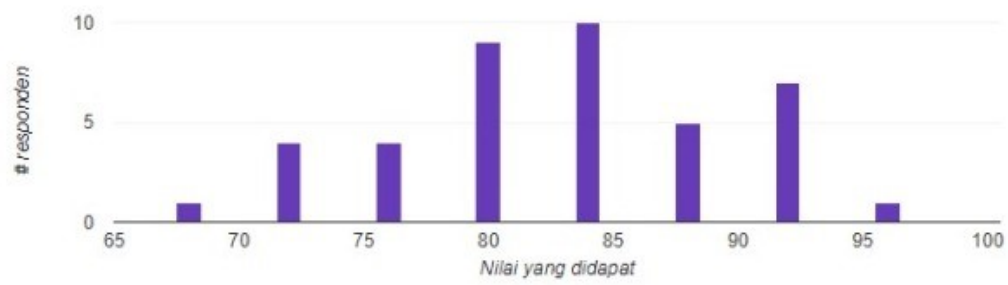

Gambar 7. Diagram Hasil Capaian Tes Menyimak

\section{2) Google Classroom}

Google classroom merupakan suatu serambi pembelajaran campuran untuk ruang lingkup pendidikan yang dapat memudahkan dosen dalam membuat, membagikan, dan menggolongkan setiap penugasan tanpa kertas. Google classroom merupakan alat produktivitas gratis meliputi email, dokumen, dan penyimpanan. Google classroom didesain untuk memudahkan dosen dalam menghemat waktu, mengelola kelas, dan meningkatkan komunikasi dengan mahasiswa. Dengan google classroom ini dapat memudahkan dosen dan mahasiswa untuk saling terhubung di dalam dan diluar sekolah.

Rosemarie De Loro, seorang guru asal New York, menyatakan selama 60 tahun dia mengajar tidak pernah sekalipun menggunakan komputer. Namun, sejak memiliki chromebook dan google classroom di dalamnya, dia bisa dengan mudah memberikan pekerjaan rumah digital kepada murid-muridnya dan memberikan tanggapan secara langsung, kapan pun dan di manapun (Biantoro, 2014).

Menurut Savitri (2019:22) pembelajaran mengggunakan alat komunikasi google classroom dapat membantu pendidik dan peserta didik melalui sebuah PC yang membutuhkan jaringan internet, namun dapat diakses dalam kelompok dalam waktu bersamaan di tempat yang berbeda-beda. 
Fungsi google classroom pada tahap design sebagai berikut: (1) kelas dapat disiapkan dengan mudah; pengajar dapat menyiapkan kelas dan mengundang siswa. Kemudian, di dalam aliran kelas, mereka dapat berbagi informasi seperti tugas, pengumuman, dan pertanyaan; (2) menghemat waktu dan kertas; pengajar dapat membuat kelas, memberikan tugas, berkomunikasi, dan melakuan pengelolaan, semuanya di satu tempat; (3) pengelolaan yang lebih baik; siswa dapat melihat tugas di halaman tugas, di aliran kelas maupun di kalender kelas. Semua materi otomatis tersimpan dalam folder google drive; (4) penyempurnaan komunikasi dan masukan; pengajar dapat membuat tugas, mengirim pengumuman, dan memulai diskusi kelas secara langsung. Siswa dapat berbagi materi antara satu sama lain dan berinteraksi dalam aliran kelas melalui email. Pengajar juga dapat melihat dengan cepat siapa saja yang sudah dan belum menyelesaikan tugas, serta langsung memberikan nilai dan masukan real-time; (5) dapat digunakan dengan aplikasi yang anda gunakan; kelas berfungsi dengan google document, kalender, gmail, drive dan formulir; dan (6) aman dan terjangkau; kelas disediakan secara gratis. Kelas tidak berisi iklan dan tidak pernah menggunakan konten atau data siswa untuk tujuan iklan.

Google classroom dapat diakses melalui dua cara yaitu melalui website dan aplikasi. Untuk website dapat diakses menggunakan browser apapun seperti chrome, firefox, internet explorer ataupun safari. Sedangkan untuk aplikasi dapat diunduh secara gratis melalui playstore untuk telepon seluler dan app store untuk iOS.

Pada penelitian ini mengundang mahasiswa ke kelas untuk mendaftar ke kelas dengan 3 cara, yaitu: (1) mengirim tautan undangan dan mahasiswa klik tautan untuk bergabung; (2) mengirim undangan melalui email dan mahasiswa dapat bergabung dari email atau di classroom; dan (3) berbagi kode kelas dan mahasiswa memasukkan kode di google classroom.

Google classroom adalah lingkungan yang tertutup. Hanya siswa yang telah bergabung atau diundang untuk bergabung dengan google classroom yang dapat melihat tugas dan pengumuman. Hal ini memungkinkan untuk nama siswa dan komentar untuk tetap pribadi. Ada beberapa fitur tampilan google classroom 
diantaranya menurut (Keeler; 2015), terdapat fitur (1) The Stream; (2) Students; (3) About; (4) Create an Assignment; (5) Upcoming Assignments;(6) Show Deleted Comments;(7) Class Code; (8) Change Class Theme; dan (9) Menu. Berikut ini fitur yang digunakan pada Mata Kuliah Keterampilan Menyimak di Program Studi Pendidikan Bahasa Indonesia, FKIP Universitas Bengkulu.

$\equiv$ Kelas Keterampilan Menyimak 1-A $\quad$ Forum Tugas Kelas Anggota Nilai $\quad$ क् :::

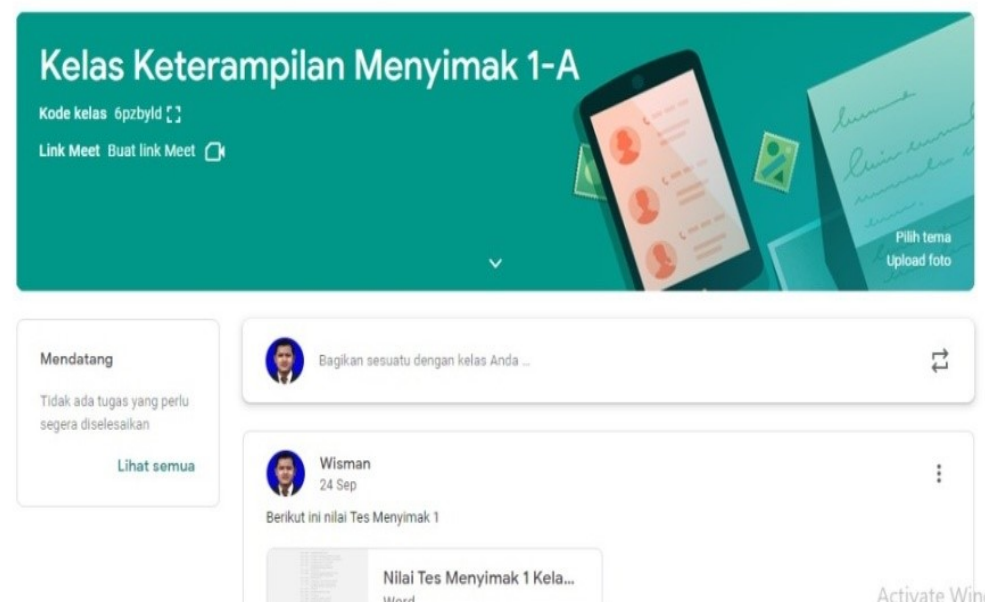

Gambar 8. Tampilan Kelas Keterampilan Menyimak Google Classroom

c. Tahap Develop (Pengembangan)

Pada tahap develop adalah kegiatan mengembangkan media pembelajaran keterampilan menyimak secara online mengunakan google form dan google classroom produk awal menjadi produk akhir. Pertama, pada tahap develop divalidasi oleh para ahli (dosen senior). Untuk memvalidasi tes diperlukan instrumen berupa lembar penilaian. Lembar penilaian dalam penelitian dan pengembagan ini akan digunakan untuk memberikan penilaian terhadap tes tertulis yang telah dibuat. Tim ahli akan memberikan penilaian dengan mengisi angket pada setiap butir penilaian dengan kriteria valid atau tidak valid. Pada butir yang dinilai belum valid, para ahli akan memberikan masukan perbaikannya lembar penilaian. Kedua, hasil kuesioner respons mahasiswa. Hal ini dilakukan untuk mengetahui kepraktisan produk yang dikembangkan dan diujicobakan. Ketiga, analisis hasil. Hal ini dilakukan untuk mengetahui keefektifan produk yang dikembangkan dan diujicobakan. 
Langkah-langkah yang dilaksanakan pada tahap uji coba pegembangan media pembelajaran keterampilan menyimak secara online mengunakan google form dan google classroom sebagai berikut:

1) Analis Hasil Validasi Ahli

Validasi dilakukan oleh para dosen senior di Program Studi Pendidikan Bahasa Indonesia FKIP Universitas Bengkulu. Validasi ini menggunakan instrumen berupa lembar penilaian. Lembar penilaian digunakan untuk memberikan penilaian terhadap tes tertulis yang telah dibuat. Sejumlah ahli akan mengevaluasi google form dan google classroom dan selanjutnya dilakukan revisi. Tim ahli akan memberikan penilaian dengan mengisi angket pada setiap butir penilaian dengan kriteria valid atau tidak valid. Pada butir yang dinilai belum valid, para ahli akan memberikan masukan perbaikannya lembar penilaian. Hasil penilaian oleh tim ahli menunjukkan bahwa media pembelajaran berbasis online menggunakan google form dan google classroom pada mata kuliah keterampilan menyimak layak digunakan, selanjutnya dapat digunakan ke tahap uji coba skala terbatas.

Penilaian validasi ahli menggunakan skala 4, yaitu 1 (kurang baik), 2 (cukup baik), 3 (baik), dan 4 (sangat baik). Rata-rata skor penilaian dari validasi ahli menjadi acuan untuk mengetahui kevalidan produk yang dikembangkan. Perhitungan rata-rata skor penilaian dari ahli dapat dilakukan sebagai berikut.

$$
X=\frac{\sum x}{n}
$$

$\mathrm{X}$ merupakan rata-rata skor penilaian ahli, $\Sigma x$ merupakan jumlah skor penilaian ahli, dan $n$ jumlah indikator penilaian dalam lembar validasi. Kriteria penilaian dari ahli dapat dilihat pada tabel berikut.

Tabel 1. Kriteria Penilaian Validasi Ahli

\begin{tabular}{cc}
\hline Skor Rata-Rata Penilaian & Kriteria Penilaian \\
\hline $3 \leq X \leq 4$ & Valid \\
$2 \leq X<3$ & Cukup valid \\
$1 \leq X<2$ & Kurang valid \\
$0 \leq X<1$ & Tidak valid \\
\hline
\end{tabular}


Berdasarkan hasil analisis data validasi ahli dapat disimpulkan bahwa pegembangan media pembelajaran keterampilan menyimak secara online mengunakan google form dan google classroom berada pada kriteria valid dengan nilai rata-rata 4,00 .

\section{2) Hasil Kuesioner Respons Mahasiswa}

Kuesioner respons mahasiswa digunakan untuk mengetahui kepraktisan produk yang dikembangkan dan diujicobakan. Produk berupa perangkat pembelajaran dikatakan efektif jika skor rata-rata hasil angket respons mahasiswa termasuk dalam kriteria baik. Penilaian menggunakan 4 skala, yaitu 1 (kurang setuju), 2 (cukup setuju), 3 (setuju), dan 4 (sangat setuju). Perhitungan rata-rata skor kuesioner respon mahasiswa dapat dilakukan sebagai berikut.

$$
X=\frac{\sum x}{n}
$$

Tabel 2. Kuesioner Respons Mahasiswa

\begin{tabular}{cc}
\hline Skor Rata-Rata Penilaian & Kriteria Penilaian \\
\hline $3 \leq X \leq 4$ & Sangat baik \\
$2 \leq X<3$ & Baik \\
$1 \leq X<2$ & Cukup baik \\
$0 \leq X<1$ & Kurang baik \\
\hline
\end{tabular}

Berdasarkan hasil analisis data kuesioner respons mahasiswa dapat disimpulkan bahwa pengembangan media pembelajaran keterampilan menyimak secara online mengunakan google form dan google classroom berada pada kriteria baik dengan nilai rata-rata 3,22.

3) Analisis Hasil Tes

Hasil tes digunakan untuk mengetahui keefektifan produk yang dikembangkan dan diujicobakan. Produk berupa perangkat pembelajaran dikatakan efektif jika skor rata-rata hasil tes mahasiswa termasuk dalam kriteria baik. Kriteria penilaian hasil tes disajikan dalam Tabel 3. 
Tabel 3. Kriteria Penilaian Hasil Tes

\begin{tabular}{cc}
\hline Skor Rata-Rata Penilaian & Kriteria Penilaian \\
\hline $3 \leq X \leq 4$ & Sangat baik \\
$2 \leq X<3$ & Baik \\
$1 \leq X<2$ & Cukup baik \\
$0 \leq X<1$ & Kurang baik \\
\hline
\end{tabular}

Berdasarkan hasil analisis data penilaian hasil tes dapat disimpulkan bahwa pengembangan media pembelajaran keterampilan menyimak secara online mengunakan google form dan google classroom berada pada kriteria baik dengan nilai rata-rata 82,93 .

\section{d. Tahap Disseminate (Penyebarluasan)}

Pada tahap disseminate dalam penelitian ini adalah kegiatan penyebarluasan media pembelajaran keterampilan menyimak secara online mengunakan google form dan google classroom. Penyebarluasan hanya terbatas penggunaanya pada Program Studi Pendidikan Bahasa Indonesia, FKIP Universitas Bengkulu. Penyebarluasan media pembelajaran dibagikan melalui grup WhatsApp dan google classroom. Tautan google form pada mulanya sangat panjang, demi memudahkan mahasiswa membuka tautan tersebut diperpendek menggunakan bantuan layanan http://gg.gg/. Tautan google form pada mulanya https://docs.google.com/forms/d/e/1FAlpQLScmQjaScZIKW4ibVg8mi8nyi5MKDU0 mklqThO4wQ5 HxMMcJg/viewform? usp=sf link, diperpendek menjadi http://gg.gg/Tes-Menyimak.

\section{Pembahasan}

Kolaborasi google form dan google classroom dapat membuat dan melaksanakan tes di manapun tanpa terikat dengan tempat dan pembiayaan yang terlalu besar. Pada dasarnya google form dan google classroom memiliki perbedaan mendasar yaitu google form berfungsi sebagai instrumen seperti peletakan soal dan penilaian, sedangkan google classroom sebagai media untuk berkomunikasi dengan mahasiswa berupa info pelaksanaan dan materi tes. Google form dan google classroom bisa dikolaborasikan penggunaannya dengan 
memfokuskan google classroom sebagai pemberian info tes, tugas, dan soal, sedangkan google form untuk pembuatan butir-butir soal yang diujikan. Di dalam google classroom juga berfungsi untuk pengelompokan nilai sesuai dengan kelasnya, contoh kelas Keterampilan Menyimak 1-A, maka di sana hanya terdapat nilai dari orang-orang yang bergabung pada kelas Keterampilan Menyimak 1-A tanpa harus milih satu persatu. Untuk proses kolaborasi, soal dibuat di google form yang kemudian diumumkan menggunakan google classroom. Unggah google form bisa dilaksanakan pada kolom tugas pada google classroom dengan menggunakan fitur upload file (fitur upload file ini juga dapat menggunakan file selain google form seperti office word).

Kelebihan kolaborasi antara keduanya adalah google classroom tidak memiliki fungsi sebagai survei yang berformat pilihan ganda serta penilaian secara langsung, maka google form sebagai pelengkap fitur yang tidak ada pada aplikasi tersebut. Berhubung keduanya terintegrasi, maka ketika selesai mengisi jawaban dan mengirim data dari peserta tes, maka akan ada laporan pada dosen sebagai pengelola google classroom bahwa mahasiswa tersebut sudah melakasanakan dan mengirim tugas.

Berdasarkan hasil analisis data validasi ahli pegembangan media pembelajaran keterampilan menyimak secara online mengunakan google form dan google classroom berada pada kriteria valid berada pada kriteria valid dengan nilai rata-rata 4,00. Penelitian ini mendukung hasil penelitian Asi (2017) dan Rachmawati \& Kurniawati (2020).

Hasil analisis data kuesioner respon mahasiswa dapat dijelaskan bahwa pengembangan media pembelajaran keterampilan menyimak secara online mengunakan google form dan google classroom berada pada kriteria baik dengan nilai rata-rata 3,22. Penelitian ini mendukung hasil penelitian Asi (2017) dan Rachmawati \& Kurniawati (2020).

Pada hasil analisis data penilaian hasil tes dapat diuraikan bahwa pengembangan media pembelajaran keterampilan menyimak secara online mengunakan google form dan google classroom berada pada kriteria baik dengan 
nilai rata-rata 82,93 . Hal tersebut menunjukkan bahwa penilaian hasil tes lebih tinggi dibandingkan dengan penelitian yang dilakukan oleh Rachmawati \& Kurniawati (2020) yang berada pada kriteria baik dengan rata-rata 80,67.

Penelitian ini berbeda dari penelitian sebelumnya karena kolaborasi google form dan google classroom. Objek yang diteliti adalah mahasiswa Program Studi Pendidikan Bahasa Indonesia, FKIP Universitas Bengkulu. Berdasarkan hasil pengembangkan media pembelajaran keterampilan menyimak secara online mengunakan google form dan google classroom yang telah dilakukan dapat dilihat pada tabel berikut.

Tabel 4. Hasil Penilaian

\begin{tabular}{cll}
\hline No. & \multicolumn{1}{c}{ Instrumen } & \multicolumn{1}{c}{ Hasil Penilaian } \\
\hline 1. & Validasi ahli & $\begin{array}{l}\text { Hasil analisis data validasi ahli berada pada kriteria valid } \\
\text { dengan nilai rata-rata 4,00. }\end{array}$ \\
\hline 2. & $\begin{array}{l}\text { Kuesioner respons } \\
\text { mahasiswa }\end{array}$ & $\begin{array}{l}\text { Hasil analisis data kuesioner respons mahasiswa berada } \\
\text { pada kriteria sangat baik dengan nilai rata-rata 3,22. }\end{array}$ \\
\hline 3. & Analisis hasil tes & $\begin{array}{l}\text { Analisis hasil tes berada pada kriteria baik dengan nilai } \\
\text { rata-rata 82,93 }\end{array}$ \\
\hline
\end{tabular}

\section{Simpulan}

Pengembangkan Media Pembelajaran Keterampilan Menyimak Berbasis Online Mengunakan Google Form dan Google Classroom layak digunakan oleh Mahasiswa Prodi Pendidikan Bahasa Indonesia FKIP Universitas Bengkulu. Hal ini ditunjukkan dengan pertama, hasil analisis data validasi ahli pegembangan media pembelajaran keterampilan menyimak berbasis online mengunakan google form dan google classroom berada pada kriteria valid dengan nilai rata-rata 4,00. Kedua, berdasarkan hasil analisis data kuesioner respons mahasiswa dapat disimpulkan bahwa pengembangan media pembelajaran keterampilan menyimak berbasis online mengunakan google form dan google classroom berada pada kriteria sangat baik dengan nilai rata-rata 3,22. Ketiga, berdasarkan hasil analisis data penilaian hasil tes dapat disimpulkan bahwa pengembangan media pembelajaran keterampilan menyimak berbasis online mengunakan google form dan google classroom berada pada kriteria baik dengan nilai rata-rata 82,93. 


\section{Daftar Pustaka}

Achsin, A. (1981). Pengajaran Menyimak. Jakarta: Penlok Tahap II P3G Depdikbud.

Afrianti, W. E. (2018). "Penerapan Google Classroom dalam Pembelajaran Akuntansi”. (Skripsi). Yogyakarta: Universitas Islam Indonesia Yogyakarta.

Asi, N. B. (2017). Pengembangan Bahan Ajar Kimia Bahan Makanan Berbasis Web. Jurnal IImiah Kanderang Tingang, 8(2). https://chemupr.education/ojs/index.php/JIKT/article/view/71

Biantoro, B. (2014). Peduli Pendidikan, Google Buat "Ruang Kelas" di Dunia Maya. 13th August. classroom.google.com.

Hamdani, Y. Y. dkk. (2017). G Suite. Bandung: Lembaga Sistem Informasi.

Hartley, D. E. (2001). Selling E-Learning. American Society for Training and Development.

Irawan. (2011). Bekerja Online dengan Aplikasi Gratis. Palembang: Maxikom.

Jahroh, N. N.. (2018). "Pengembangan Tes Tertulis Pendidikan Agama Islam Berbasis Online Mengunakan Google Form pada Materi Kewajiban Menuntut IImu dan Haji Kelas X SMA Swadhipa Natar". (Skripsi). Lampung: Universitas Islam Negeri Raden Intan Lampung.

Keeler, A. L. M. (2015). 50 Things You Can Do with Google Classroom. San Diego, CA: Dave Burgess Consulting, Inc.

Keputusan Bersama 4 Menteri Nomor 01/KB/2020 tanggal 15 Juni 2020 tentang Panduan Penyelenggaraan Pembelajaran pada Tahun Ajaran 2020/2021 dan Tahun Akademik 2020/2021 di Masa Pandemi Corona Virus Disease (Covid-19)

Keraf, G. (1997). Komposisi. Flores: Nusa Indah.

Kridalaksana, H. (1984). Fungsi Bahsa dan Sikap Bahasa. Bandung: Ganaco.

Mansor, A. Z. (2012). Managing Student's Grades and Attendance Records Using Google Form and Google Spreadsheets. Procedia-Social and Behavioral Sciences, 59, 420-428. https://doi.org/10.1016/j.sbspro.2012.09.296. Diunduh tanggal 7 April 2020.

Maulidi, A. (2015). Pengertian Belajar Online. Kanal Pengetahuan. https://www.kanal.web.id/2015/09/pengertian-belajar-online.html. 
Noermanzah, N. (2019). Bahasa sebagai Alat Komunikasi, Citra Pikiran, dan Kepribadian. Seminar Nasional Pendidikan Bahasa dan Sastra, Prosiding Seminar Nasional Bulan Bahasa (Semiba), 307, https://ejournal.unib.ac.id/index.php/semiba/article/view/11151/5537

Nursaid. (2001). Pengajaran Keterampilan Menyimak. Padang: FBSS UNP.

Rachmawati, R., \& Kurniawati, A. (2020). Pengembangan Instrumen Penilaian Tes Berbasis Mobile Online pada Prodi Pendidikan Matematika. Prima: Jurnal Pendidikan Matematika, 4(1), 46. doi:10.31000/prima.v4i1.1891

Savitri, D. I. (2019). Penggunaan Pembelajaran 4.0 Berbantuan Aplikasi Google Classroom dan Google Form Dalam Mata Kuliah IImu Sosial Budaya Dasar. Jurnal Borneo Saintek, 2(1), http://jurnal.borneo.ac.id/index.php/borneo saintek/article/view/632/0

Solihah, A. dkk. (2015). Latihan Soal UKBI. Jakarta: TransMedia.

Sugiyono. (2012). Metode Penelitian Kuantitatif, Kualitatif dan R\&D. Bandung: Alfabeta.

Tarigan, H. G. (1986). Menyimak sebagai Suatu Keterampilan Berbahasa. Bandung: Angkasa.

Thiagarajan, S., Semmel, D., \& Semmel, M. (1974). Instructional Development for Training Teachers of Exceptional Children: A Sourcebook. Retrieved from https://eric.ed.gov/?id=ED090725

Wiranty, W. (2019). Peningkatan Keterampilan Menyimak Komprehensif dan Kritis dengan Metode Resitasi pada Mahasiswa. Edukasi: Jurnal Pendidikan, 17(1), 112. doi:10.31571/edukasi.v17i1.1082 